\title{
The Clash of Global Hegemonies
}

\author{
James Lull1 \\ San Jose State University
}

\begin{abstract}
For the first time in history, religion is being discussed for what it truly is-dominant ideology of the most dangerous kind propelled by myth and ritual that is backed by enormous institutional force. In the case of Islam, the ultimate goal is nothing less than a totalizing global hegemony that aims to impose the religion on everyone-the "ummah." Terrorism is but the most visible, ragged, sharp edge of a much larger and ultimately more dangerous movement. The hegemony of Western-especially AmericanAnglo-power and interests has long been recognized and properly criticized. And for now, the policies and rhetoric of George W. Bush and Tony Blair have undermined any remaining moral authority the West might offer. The modern world has been stuck in recent years with the wrong messengers to respond to the Islamists' ambitions. Television and the internet, together with the culture industries and personal communications technology, work together to create communicational space where these competing hegemonies have become much more transparent than before. This article explores why the undetermined, open spaces of global communication offers the greatest hope for long-term reduction of threats posed by any variety of global power.
\end{abstract}

Key words: hegemony, western power, Islam, media, hope.

1 James Lull is Professor Emeritus of Communication Studies at San Jose State University, California, USA. He is the author of several books including Culture-on-Demand:

Communication in a Crisis World (Blackwell, to be published in 2007); Culture in the Communication Age (Routledge, 2001); Media, Communication, Culture: A Global Approach (Polity Press, 2000); Media Scandals (Polity Press, 1997); Popular Music and Communication (Sage, 1992); Inside Family Viewing: Ethnographic Research on Television's Audiences (Routledge, 1990). 
Resumo: Pela primeira vez na história, a religião está sendo discutida pelo que ela realmente é - ideologia dominante do tipo mais perigoso, impulsionada por mito e ritual, e que é apoiada por enorme força institucional. No caso do Islã, o objetivo final é nada menos que uma hegemonia global totalizante que tenta impor uma religião para todos $-a$ "ummah". O terrorismo é somente o mais visível, áspero, fio afiado de um movimento muito maior e, em última instância, mais perigoso. A hegemonia de poder e interesses do ocidente - especialmente, anglo-saxão - foi há muito reconhecida e devidamente criticada. E por ora, as políticas e a retórica de George W. Bush e Tony Blair enfraqueceram qualquer autoridade moral que o ocidente poderia oferecer. Nos anos recentes, o mundo moderno ficou preso aos mensageiros errados para responder às ambições islâmicas. A televisão e Internet, juntamente com as indústrias culturais $e$ as tecnologias de comunicação pessoal, trabalham em conjunto para criar um espaço comunicacional onde estas hegemonias competitivas se tornam muito mais transparentes do que anteriormente. Este artigo explora por que os espaços abertos de comunicação global indeterminados oferecem a maior esperança, em longo prazo, para a redução dos perigos apresentados por qualquer tipo de poder global.

Palavras-chave: hegemonia, poder do ocidente, islã, mídias, esperança.

Staggering to defend a misguided and failed war in Iraq, and hoping to literally scare up votes for America's last midterm election, U.S. President George Bush and his minions intensified the rhetoric of fear in the fall of 2006. War critics, they said, suffer "moral confusion." No "appeasement" of the enemy this time around. The West is at war with "Islamo-fascist terrorists."

Media pundits responded loudly to the American administration's fanciful spin on history and the coordinated deployment of the supremely hot-button term, "fascist." MSNBC's Keith Olbermann, a rising star in American cable television, delivered blistering rants about Secretary of Defense Donald Rumsfeld's speeches and the Bush team's constant attacks on war critics and civil liberties. Olbermann made incisive and courageous commentaries about the White House's disdain for criticism and what he called the American government's arrogance and air of omniscience. He argued that America's 
political leaders have acted much the same way England's government marginalized debate about the Nazi threat in the 1930s. Neville Chamberlain's government thought it had all the facts then too, no questions need be asked. Bush, Rumsfeld, and Vice President Dick Cheney assured the world that they too have information with which only they can be trusted. To avoid moral confusion, they say, Americans and others should defer to their judgment. Disagreement and dissent only encourage the enemy.

That kind of blatant authoritarianism and unscrupulous fear mongering from the American government, Olbermann warned in his nightly program, puts all citizens at risk: "Our country faces a new type of fascism-indeed."

Converging trends-especially the harsh realities in Iraq as described in Pentagon reports and subsequent analyses last fall, plunging opinion polls, and an increasingly critical media view of the Bush and Blair approach to fighting terrorism—all cast healthy doubt on any pronouncements coming from the White House or the Pentagon, no matter how alarming. So it follows that when President Bush declares repeatedly that America and Britain are engaged in the most important ideological struggle of the early $21^{\text {st }}$ Century-a war with the dreaded "Islamo-fascists"- the public no longer swallows the official analysis whole. When arch conservative Republican Senator Rick Santorum from Pennsylvania calls the war on "Islamic fascists" the greatest challenge ever in America's history, as he announced on Meet the Press, an important weekend interview program in the United States, people hear fear-driven campaign rhetoric above all else. And for good reason.

Much gets lost in the fog of war. Add the fog of the political season and things become nearly impossible to see. Where do the real threats to America, Britain, and the West come from today? From Islamo-fascist terrorists who threaten our very lives? From our own governments that curtail civil liberties and ask for unwarranted blind trust? From the deep suspicion and vitriol that the Bush-Blair foreign policy has engendered around the world?

We struggle to see through the fog in part because the Bush Administration has made the tragic mistake of starting a war in Iraq whose main effect has been to further stir resentment and rage among Muslims in the Middle East. Everything Bush and company 
say now comes across as manipulative and self serving. They've earned our profound distrust.

Through all this, however, one truth should not be lost. The modern world truly is engaged in an unprecedented ideological struggle. There is an important message to get out about an alarming problem today-the true nature of Islamic fundamentalism and the global designs of its proponents. For the first time in history, people the world over have begun to talk about religion for what it truly is - dominant ideology of a unique kind that is propelled by myth and ritual and backed by enormous institutional force. In the case of Islam, the ultimate goal is nothing less than a totalizing global hegemony.

So it's unfortunate that the modern world is stuck with the wrong messengers to respond to the ideological assault of Islamic fundamentalism. The choice by Bush's strategists and speech writers to use the term "fascist" to describe Islamists is not completely off the mark. But who in the world grants the American administration moral authority on this or anything else anymore? Bush's uttering the oft-repeated phrase, "We're engaged in the ideological struggle of the $21^{\text {st }}$ Century" actually undermines the truthfulness of the claim. Furthermore, the use of the term "fascists" to describe Islamist totalitarianism seems inappropriate to many (hence the dropping of the term by White House spokespersons in late 2006). The kind of fascism that lingers in our collective memory signals state-sponsored terror like Nazi Germany and Mussolini’s Italy—precisely what we don't face today.

But a more general meaning of fascism-totalitarianism, a radical belief in the superiority of one's ethnic group, a determined destiny — in fact well describes a movement that is underway and not subject to recall by democratic vote. At the very time Bush, Rumsfeld, Cheney, and their supporting cast were stoking fear with political rhetoric during 2006 midterm elections, two Islamists were also making international news. Ayman alZawahiri, Al Qaeda's angry second in command, and Adam Gadahn, the California-born Islamist who frequently voices the terrorist group's messages when they are directed to the United States, demanded that Americans immediately convert to Islam. "Decide today," Gadahn sternly warned on an internet speech circulated by global television, "because 
today could be your last day." That invective was widely interpreted as a warning that another terrorist attack was on the way. But the significance of this "invitation to Islam" transcends the threat of any act or promise of terrorism.

American power is rightly feared throughout the world, especially now. The nation's military might has never been stronger or less contested by other nation states. Foreign policy under President Bush has become the very definition of how a certain type of ideological hegemony can be brutally exercised on a global scale. At the same time, ideologically powerful Islamic fundamentalist leaders-supported by an enormous number of believers worldwide, not just the terrorists-have initiated their own global hegemony. This serious ideological ambition is the ummah, global domination by Islam. We're witnessing a clash between two "universalisms," observes Syrian-born Islamic scholar Bassam Tibi in The Challenge of Fundamentalism (2002). One is secular, the other divine, he says, "each claiming global validity" (Tibi 2002: 61). Islamic "ethno-fundamentalism," Tibi argues, has become "the most recent variety of totalitarianism" on the world stage, and the most extreme. In a recent attempt to silence dissent within Islam, to cite but one recent example, twelve highly-visible Muslim-born intellectuals including Salman Rushdie, Irshad Manji, and Ayaan Hirsi Ali have been issued death threats by British Islamists on their website, ummah.com.

As Islamists lash out against Western culture, it isn't just the terrorists, suicide bombers, and fanatical clerics who threaten secular societies. The underlying structure of the faith and its predominant vision for the future rest upon one undeniable fact: political and cultural history for the past 1,000 years threatens what is clearly promised in the Koran-a world ruled by Islam. Western global supremacy today thus interferes with Muslims' own imperialistic and explicitly hegemonic ambitions. Western influence represented by modernization, globalization, and the presence of infidels in the Middle East are considered by many to be evil forces that threaten God's plan.

The passion of the religious culture runs deepest in the Islamic world. While highly-visible radical Islamists express the most visible resistance to the sharp edges of modernity and globalization, their rhetoric and the symbolic force of their actions 
represent a cultural view that long pre-dates the current wave of violence. It's a general attitude that is tacitly accepted by millions more. The most consequential obstacle to lasting global peace and cultural progress in the Muslim world, according to Irshad Manji, is not the terrorists or the radical fringe. It is the "paralyzing sickness of the entire religion—-the untouchability of mainstream Islam” (Manji 2003: 49; italics mine).

Religious conviction with minimal reflection and little or no sense of true universal humanity creates a deadly dangerous worldview. It happens even at an unconscious level. As Manji points out, "Most of us Muslims aren't Muslims because we think about it, but rather because we're born that way. It's 'who we are" (Manji 2003: 16). Nothing that faintly resembles The Enlightenment has intervened to relativize the extreme perspective of the faith. Most Muslims have lived in cultural isolation for centuries. That's why it's fair to say that mainstream Islam has become the dominant "culture of complicity" in the world today (Manji 2003: 63; italics mine), and that "the number of passive Muslim supporters of terrorism is far greater than Westerners want to contemplate" (Hotaling 2003: 165). Or as one of the few moderate Islamic spokespersons with international influence has put it, the fanatical Muslim groups are only "extreme manifestations of more prevalent intellectual theological currents in modern Islam" (El Fadl 2002: 7-8).

Of course, asserting the claim that (our) God alone embodies absolute truth has been a characteristic of all monotheistic religions over the millennia. But the infallibility conceit persists more in Islam than in Christianity and most other faiths, is thought to be backed up by a command from Muhammad to eliminate all rivals, and is woefully out of step with progressive trends in modernity, including the way other monotheistic faiths have become more integrated into secular global realities (Cook 2000: 33). It wasn't terrorists who outlawed the practice of religions other than Islam, punishable by imprisonment and even death, as an Islamic principle. Polytheism (shirk), the worship of any God other than the "one true God," has represented the ultimate wrong in Islam throughout the religion's history. Apostasy — personal abandonment of the faith—is subject to punishment of death in Islamic law. Apostasy was considered a capital offense in early Judaism and Christianity too, but "of the Abrahamic faiths Islam stands alone in its inability to renounce this barbaric doctrine convincingly" (Dennett 2006: 289). 
The word Islam means to "submit" or "surrender" to God's will. A Muslim is "one who surrenders." Although submission or surrender to higher religious authority is by no means peculiar to Muslims, unique and compelling factors stand out when considering the special case of Islamic fundamentalism. First is the sheer number of Muslims worldwide, estimated to range between one and two billion people. That number will continue to grow absolutely and in proportion to other religious groups, mainly because of the spiraling birth rate in Muslim countries. Second is the degree of submission to God expected of Islamic faithful compared to other groups whose fundamentalism has been tempered by secular authority and political history. There is no expression in Arabic for "Muslim moderate," explained Khaled Abou El Fadl to the World Affairs Council in San Francisco, "only for 'extremist' or 'Muslim”' (El Fadl 2005).

Developing greater tolerance requires that people put their cultural biases into some kind of basic perspective-relativizing their views by granting that others legitimately may hold beliefs and loyalties that differ from their own. Those views must be respected, and the right of others to express contrasting views should also be protected. That's very difficult for any fundamentalist-thinking person to do, especially religious fundamentalists. Fundamentalists make up significant numbers of all the major monotheistic religionsJudaism, Christianity, and Islam. The two proselytizing camps among these three are Christians and Muslims. These religious groups ambitiously seek converts who need not hold any special qualifications for joining up, although new Muslims must abide by extremely strict guidelines for practicing the faith or face the possibility of severe punishment.

\section{Refusing to Reason}

The underlying cause of this extremism is clear. Religious fundamentalists of all denominations willingly, even proudly, refuse to make use of the one ability that separates human beings from all other living organisms-the capacity to reason. As Sam Harris writes in the best-selling book The End of Faith

Tell a devout Christian that his wife is cheating on him, or that frozen yogurt can make a man invisible, and he is likely to require as much evidence as anyone else, and to be persuaded only to the extent that 
you give it. Tell him that the book he keeps by his bed was written by an invisible deity who will punish him with fire for eternity if he fails to accept its every incredible claim about the universe, and he seems to require no evidence whatsoever (Harris 2005: 19).

In a starkly revealing and well-known case about the nature of religious fundamentalism, Muslims the world over responded angrily, sometimes violently, to the publication of cartoons of Muhammad by a small Danish newspaper in 2005, and the global circulation of those images by television and other media. The reaction surprised people outside the Muslim world. Media attention to the issue continued for weeks. Especially for Westerners living in pluralistic secular societies, the idea that everythingincluding religious beliefs — can be subjected to criticism and debate, even insult and humiliation, is basic to modern life. While many in the West could appreciate that Muslims' religious sensitivities may have been disturbed by publication of the cartoons, few could comprehend why the event would provoke such an extreme and widespread reaction.

Similar protests went on unabated for weeks a year later when Pope Benedict XVI stirred global Muslim wrath with comments he made during a speech delivered at the University of Regensburg in his native Germany. The purpose of the speech, according to Vatican officials, was to open a "frank" and direct "interfaith" dialogue about how violence could be reduced in a world that is so obviously inflicted by ideological and cultural conflict rooted in differences between the monotheistic religions. In the speech, the Pope quoted a medieval Byzantine emperor, Manuel II Paleologus, who had claimed that Islam is "evil and inhuman" and that Muhammad added nothing positive to the Abrahamic ecumenism of the time except violence. Pope Benedict then linked that quotation to the fundamental Islamic concept of jihad, calling it "holy war." The Pope was making an overall argument about how violence that is inspired or sponsored by any religious group does not accord with "God's plan" for humanity. It was that larger point—which included the Pope's admitting that the same kind of religious-inspired violence has also been wrongly committed by Christians - that was interpreted by many Muslims as blaming Islam for spreading their faith "by the sword." 
In response to media reports about the Pope's remarks, Muslim protestors took to the streets from Indonesia to Iran, from Egypt to England. Some burned the Pope in effigy. The German flag was torched. Christian churches were incinerated in the Gaza Strip. Turkish Muslims demanded the Pope cancel an upcoming visit. Muslim clerics in Pakistan asked the Pope to resign. Morocco withdrew its ambassador to the Holy See. The Vatican was put on high security alert. Islamists posted warnings on the internet threatening war against "worshippers of the cross." Many ordinary Muslims saw the Pope's comments as part of a Crusade being waged against Islam that had been initiated by President Bush's military interventions in Afghanistan and Iraq. Religious spokesmen representing 56 Islamic nations demanded that Benedict "retract or redress" his remarks. The Pope's repeated effort to explain the context of his remark-quoting an historical figure in order to call attention to the destructive relationship between religion and violence-only stimulated further outrage. The simple act of questioning the Islamic prophet had been deemed unacceptable by many Muslims worldwide.

Neither the prophet nor the Koran - the primary text on which not only religion, but much of basic education is based throughout the Muslim world-are allowed to be criticized in any way within Islam. Chapter 2.1 of the Koran plainly states, "This Book is not to be doubted" (The Koran 1999: 11). Furthermore, no image of Muhammad of any kind can be created-hence the dual problem for Muslims that had been caused by publication of the critical cartoons in Denmark. No criticism. No images. In a globalized world where information and imagery flows so freely from place to place regardless of geographic or cultural barriers, the great majority of Islamic believers for the first time have had to confront the unthinkable_-critical reflection on the foundations of their imperious belief system.

Rather than discuss, debate, or just thoughtfully reflect on what the Pope was trying to say in his academic presentation, many Muslims reinforced the very point that was at issue by responding with indignant outrage, even violence. During four consecutive days of constant apologizing, Benedict expressed "sincere regret" and sadness that his comments had been interpreted the way they had been by so many Muslims. He said he was personally sorry for the reaction the speech provoked, and was remorseful that he had 
hurt the feelings of so many Islamic believers. He repeatedly assured Muslims that he respects Islam. The Pope deployed Vatican ambassadors to Muslim states to quell the furor, and held a meeting at the Vatican to express his regret—an event that was televised throughout the Muslim world by Al-Jazeera.

In the West, many religious authorities and some media outlets said they believed the Pope had chosen his words unwisely. The New York Times, which the year before had refused to reprint the controversial cartoons of Muhammad for fear of further aggravating Muslim sensitivities, called the pontiffs words "ill-considered" and "unfortunate." Vatican expert Alberto Melloni was quoted by the newspaper as saying "pushing these buttons...will not help the future of religious dialogue, neither for Muslims nor for us." Some citizens expressed concern that the Catholic Pope offending Muslims could lead to more terrorism directed against innocent life in non-Muslim majority countries. A leading opera house in German quickly cancelled the performance of "Idomeneo" because it's dramatic and critical portrayal of religious prophets, including Muhammad, was thought likely to inspire a violent reaction from Muslims in Berlin and elsewhere.

But another popular and more productive sentiment also surfaced as news and opinion about the controversy continued to appear in the media. Some Christians and non-Christians in the West said they felt the Pope had nothing for which to apologize. In fact, many agreed with the essence of his argument - that no religion should tolerate or employ violence to spread its influence, including Islam, and that inter-faith dialogueespecially between Christians and Muslims-is a good idea. Moreover, as many pointed out, the main purpose of the Pope's speech was not to chastise Islam. Ironically, the primary objective of the speech was to criticize the West for submitting itself too much to reason, and shutting belief in God out of science and philosophy. The point of that critique of the West, of course, also applies to the Islamic world. Given all this, the National Catholic Reporter called the Pope's comments "A challenge, not a crusade" (Allen 2006). Andrew Sullivan, one of America's foremost bloggers, a Christian, questioned "the fact that the Pope has to apologize for intellectual engagement of a vital topic, while the West shrugs off the Muslim violence and murder that has ensued, is a terrible portent in this civilizational struggle between fundamentalism and reasoned, humble faith" (Sullivan 
2006). Under pressure from citizens at home and abroad, directors of the German opera house reconsidered their decision and staged the production under tight security.

Top columnists from the New York Times, departing from the paper's official editorial position, weighed in on the issue too. Thomas Friedman upbraided "the politically correct, kid-gloves approach of how to deal with Muslims that is taking root in the West today." He argued that contrary to popular perception, the Pope was treating Islam "with dignity" because he challenged Muslims to accept responsibility for their ideas and enter into a mature conversation with others about their belief system and actions inspired by it. Friedman claimed that more than talk between the major religions, what is needed is respectful dialogue within Islam itself. He said that Sunni and Shiia Muslims blowing up each other's mosques, especially during Ramadan and other holy days, hardly cultivates an understanding of Islam as the peaceful religion its adherents frequently proclaim. "I don't get it," Friedman wrote. "How can Muslims blow up other Muslims on their most holy day of the year-in mosques! - and there is barely a peep of protest in the Muslim world...yet Danish cartoons or a papal speech lead to violent protests" (Friedman 2006: A23).

And David Brooks, a colleague of Friedman on the New York Times editorial pages, insisted that

\begin{abstract}
Millions of Americans think the Pope asked just the right questions... What these Americans see is fanatical violence, a rampant culture of victimology and grievance, a tendency by many Arabs to blame anyone other than themselves for the problems they create. These Americans don't believe they should lower their standards of tolerable behavior merely for the sake of multicultural politeness, and they are growing ever more disgusted with commentators and leaders who are totally divorced from the reality they see on TV every night...Extremism is not an isolated cult in the Muslim world. It is a diverse and vibrant movement, which inspires the smartest of the young and treats the psychological wounds of those who are trapped between tradition and modernity" (Brooks 2006: A31).
\end{abstract}

\title{
Global Reason and Tolerance
}

Islamic outrage over the cartoons and Pope Benedict's speech represent an assault on the very attribute that is so desperately needed today in discussions about religion and 
culture-reason - and the most beneficial effect that reason can produce-tolerance. Political cartoons that mock the leaders of social institutions-popes, prophets, and presidents among them-is a time-honored and vital form of criticism in the West. When functioning at their best, art and media serve as powerful checks on the power exercised by ideologues. It is in that same spirit that the Pope said he intended his speech to be "an invitation to frank and sincere dialogue, with great mutual respect." He called for the "genuine dialogue of cultures and religions that is so urgently needed today." In the meeting held with Muslim ambassadors subsequent to the extreme reaction caused by his comments, the Pope said he hoped that Christians and Muslims could "work together...in order to guard against all forms and intolerance and to oppose all manifestations of violence."

Pope Benedict certainly got the attention of many Muslims with his academic address in Germany, and he did create significantly more interfaith interaction. In an uncomfortable way a certain kind of essential dialogue was promoted. Some authorities believe the Pope was aiming for just the kind of "hardheaded confrontation" he got. "He knew exactly what he was doing," argued Catholic theologian and papal biographer George Weigel. The real question the Pope raised, Weigel says, is "Does a significant part of Islam have the capacity to be self-critical" (Meacham 2006: 37).

For the immediate future, as the reaction among so many Muslims makes clear, hopes for moving any productive dialogue along among religious groups remain out of the question. Dialogue requires sophisticated partners in communication-individuals who can put their views on religion or any other sensitive topic into basic perspective. Everything that is valued in dialogue-nuance, subtlety, context, argument, respect for difference, understanding, compromise-is completely missing in global flare-ups like the ones described here. When the Catholic Church, especially as represented by this deeply conservative Pope, comes across as the more reasonable voice in the situation, then we have clear evidence that the world truly faces a problem that extends way beyond the perils of religious terrorism. 
Greater tolerance is the only way out of fundamental discord between such powerful parochial groups. However, in no way can tolerance be considered an Islamic value. Tolerance is certainly not the historical hallmark of Christianity either, of course, especially not among the two major forces at work today in the Christian world todayCatholicism and Evangelicalism. So where does that put us? As Richard Dawkins implores in The God Delusion, it's time for rational people everywhere to finally take an aggressive stand against religion's destructive influence (Dawkins 2006).

Karl Popper argued as World War Two drew to a close that "any movement preaching intolerance places itself outside the law, and we should consider any incitement to intolerance and persecution as criminal" (Popper 1945: 265). Popper was condemning the most damaging of human tendencies. Intolerance implies not just a lack of tolerance; agents of intolerance actively advocate narrow-mindedness, dogmatism, and bigotry. Today, fundamentalist intolerance of any variety can no longer be tolerated by the world community. Refusing to tolerate intolerance, as Popper said, must become a global priority.

Now, as in Popper's day, the antidote for intolerance is the robust circulation of information and open exchange of ideas. Fortunately, the technological and industrial resources that make this possible today are a thousand times more developed than they were when Popper wrote. The mass media, the culture industries, and the internet act as a global echo chamber, saturating the world with information that keeps refracting and accumulating through direct and mediated social networks. The massive effect this process has on the consciousness of people everywhere is monumental. One certain consequence for the short term is that differences among cultural groups will continue to intensify, even to the point of more violent confrontations. The presence of more information and greater "cultural transparency" (Lull 2007) will provoke "a rough transition before [their] advantages crystallize around us" (Brin 1998: 329).

\section{The Discursive Ummah}

Religious appeals have appeared in political discourse throughout modern history. But with the blatant exception of recent trends in the United States, especially during the tenure of born-again fundamentalist Christian George W. Bush, invoking God and 
religion's presence in public life in the West has declined greatly in recent decades. It is precisely the decline of religion's role in daily life in West, in fact, that prompted Pope Benedict XVI to issue a call for a greater role of religion in everyday life, the main purpose of his controversial academic address. The problem the Pope was describing is particularly acute among Europe's secular societies, including the nations of strong Catholic tradition like Italy and Spain, where church attendance and related activities have been waning for many years.

In the Muslim world(s), however, radical religious rhetoric continues to dominate public discourse. Historically, this communication has been confined mainly to Islamic nations and the mosques of Islamic outposts in Europe and elsewhere. Now, because of media and cultural globalization, especially satellite television, religious appeals travel much farther and reach many new audiences. For that reason those appeals have also become more visible, transparent, and subject to criticism. Consider how Iran's President Mahmoud Ahmadinejad addressed his audience in a speech given to the $60^{\text {th }}$ Session of the United Nations General Assembly in September, 2006 (Information Clearing House 2006). Ironically, his comments before the UN took place while the controversy over Pope Benedict's remarks about Islam was still simmering. The political objective of Ahmadinejad's speech ostensibly was to criticize Anglo-American hegemony in the Middle East, and to argue that Iran was complying with the requirements placed on it by the United Nations for nuclear development. Analysts focused on the political content and tone of the presentation. But what were the true nature and more basic purpose of the speech? What was the president of Iran really saying?

After first claiming to speak "In the Name of the God of Mercy, Compassion, Peace, Freedom, and Justice," Ahmadinejad made the following assertions:

With the passing of the era of agnostic philosophers, today humanity is once again joined in celebrating monotheism and belief in the Creator as the originator of existence. This is the common threat which binds us all. Faith will prove to be the solution to many of today's problems. The Truth will shine the light of faith and ethics on the life of human beings and prevent them from aggression, coercion, and injustice and will guide them toward care and compassion for fellow human beings 
He quoted the Koran and Islamic ideology throughout the speech, continually emphasizing the "twin pillars of justice and spirituality," and concluded his lengthy presentation by saying

From the beginning of time, humanity has longed for the day when justice, peace, equality, and compassion envelop the world. All of us can contribute to the establishment of such a world. When that day comes, the ultimate promise of all divine religions will be fulfilled with the emergence of a perfect human being who is heir to all prophets and pious men. He will lead the world to justice and absolute peace.

Ahmadinejad then closed his speech with a prayer:

Oh mighty Lord, I pray to you to hasten the emergence of your last repository, the promised one, that perfect and pure human being, the one that will fill this world with justice and peace.

And Ahmadinejad is Iran's political chief, an elected technocrat with an engineering background, not its religious leader. Still, his words were not mere stylistic flourishes designed to dress up drab political rhetoric.

Who is the "perfect human being, heir to all prophets and pious men" of whom Ahmadinejad speaks? If Islamists like him had their way, the perfect human being would live in a religious state under repressive cultural restrictions. We need only took at Iran today where satellite dishes are routinely confiscated by the government; internet sites are blocked; dissidents are jailed; restaurants must not serve women wearing makeup; stores may not sell tee shirts emblazoned with pop culture imagery; men cannot wear Westernstyle neckties at work; no Western music, including classical music, is aired on the state broadcasting system. Music is not allowed in malls, dancing and kissing is not permitted in public, and no partially nude mannequins may appear in store windows. Women can't attend soccer games and must sit in separate areas in mosques and buses. Iran's famed dancer Farzaneh Kaboli and two dozen of her students were incarcerated recently for performing folk dances before an all-female audience and released from jail only when they promised to never perform in "public" again.

The code words Ahmadinejad used throughout the speech to describe the imagined state of Islamic hegemony, the global ummah, are, as mentioned above, the "the 
two pillars of justice and spirituality." Justice in this context does not refer to social justice in the same civil, secular, democratic sense that is recognized, for instance, by the United Nations. Justice, as Iran's president imagines it, refers to the day when Islam rules the world. Only then will the world's peoples know justice. Quoting the Iranian leader from the speech, "As the eminent daughter of the Prophet of Islam has said, "justice brings tranquility and harmony to our hearts." Moreover, justice can only be achieved through "monotheism," as Ahmadinejad claims, wherein Islam absorbs all other religions into a final regimen of global Islamic hegemony. That's where the second pillar, spirituality, comes in. The final conversion of everyone on Earth to Islam creates a holy union where justice fuses seamlessly with spirituality in the glory of God. When read through the interpretive frame of religious ideology, it becomes clear that the holy marriage between “justice and spirituality” is what Ahmadinejad's address to the United Nations really was all about.

\section{Conclusion}

Mahmoud Ahmadinejad's flowery speech to the United Nations was not the highlight of that important 2006 meeting. Venezuelan president Hugh Chavez caught everyone's attention and won tremendous approval with his provocative "Bush is a devil" remark in his speech before the UN the next day. Members of the General Assembly uncharacteristically broke into loud applause for Chavez' highly-stylized observationsapplause that was so loud and lasting that members had to be told by UN officials to quiet down. "The devil came here yesterday," Chavez quipped, about the man he says "acts like he owns the world....It smells of sulfur still today, this table where I am standing." Chavez flashed the Catholic sign of the cross, and responded to the enthusiastic response with a broad grin. His diatribe against American hegemony had found many supporters in the room and around the world.

Hugo Chavez' confidence that "the world is waking up" to the abuse of institutional power is right on the mark. What makes that possible? The global awakening depends primarily on the power of transnational television, the culture industries, and information technology to instigate the reflection, comparison, self-criticism, and sense- 
making that is needed to raise global awareness, shape opinion, and, ultimately, foster greater tolerance. The Bush administration's actions and rhetoric, the secrets of Abu Ghurayb Prison, beheadings by Islamists, the publication of the cartoons in Denmark and the reaction they caused, the stinging comments by Pope Benedict, the haggling over whether or not the provocative German Opera should go on, Ahmadinejad's thinly veiled Islamic proselytizing, Chavez' blunt message, the question of whether Madonna should have the freedom wear a crown of thorns and strap herself to a cross as part of her show-all these controversies and thousands more reflect the most significant roles television and other communications technologies can play on the global stage. They do so by creating the necessary visibility, transparency, and cross-cultural conversations about crucial matters that touch us all-first and foremost about the nature of the competing hegemonies that are today being exposed for what they truly are.

\section{References:}

Allen, J.L. (2006). “A challenge, not a crusade.” The New York Times, Sept. 19 , p. A25.

Brin, D. (1998). The Transparent Society. Reading, MA: Perseus Books.

Brooks, D. (2006). "Lessons from U.N. week.” The New York Times, Sept. 21, p. A31.

Cook, M. (2000). The Koran. Oxford: Oxford University Press.

Dawkins, R. (2006). The God Delusion. Boston: Houghton Mifflin.

Dennett, D. (2006). Breaking the Spell. New York: Viking.

El Fadl, K. A. (2005). The great theft. Wrestling Islam from the extremists. Address given at the World Affairs Council, San Francisco. October 12.

El Fadl, K. A. (2002). The Place of Tolerance in Islam. Boston: Beacon.

Friedman, T. (2006). "Islam and the Pope." The New York Times, Sept. 29, A23.

Harris, S. (2005). The End of Faith. New York: Norton. 
Hotaling, E. (2003). Islam without Illusions. Syracuse, NY: Syracuse University Press.

Information Clearing House (2006). www.informationlearinghouse.info/article10336.htm

Lull, J. (2007). Culture-on-Demand: Communication in a Crisis World. Oxford: Blackwell.

Manji, I. (2003). The Trouble with Islam Today. New York: St. Martin's Press.

Meacham, J. (2006). “The Pope's 'holy war.” Newsweek, September 25, pp 36-7.

Popper, K. (1945). The Open Society and its Enemies. (2 ${ }^{\text {nd }}$ Ed.) London: Routledge.

Sullivan, A. (2006). Islam and reason. http://time.blogs.com/daily dish. Sept 19.

The Koran (1999). London: Penguin.

Tibi, B. (2002). The Challenge of Fundamentalism ( $2^{\text {nd }}$ ed.). Berkeley, CA: University of California Press. 